\title{
Penerapan Model Pembelajaran Probing Prompting pada Pembelajaran IPA Di SMP 3 Selong
}

\author{
${ }^{1}$ Kholida Ismatulloh, ${ }^{2}$ Ropikoh \\ ${ }^{1}$ Prodi Pendidikan Informatika, FMIPA, Universitas Hamzanwadi, Jln. TGKH Muhammad \\ Zainuddin Abdul Madjid No. 132 Pancor, Selong, Lombok Timur, NTB 83611 \\ ${ }^{2}$ SMPN 3 Selong, JL. Pahlawan, No. 170, Pancor, Sandubaya, Selong, Kabupaten Lombok \\ Timur, Nusa Tenggara Bar. 83619 \\ Email Korenspondensi: kholida.ebtaryadi@gmail.com
}

\begin{tabular}{|c|c|}
\hline$A r$ & act \\
\hline $\begin{array}{l}\text { Article History } \\
\text { Received: } 25 \text { April } 2021 \\
\text { Revised: } 20 \text { June } 2021 \\
\text { Published: } 30 \text { June } 2021\end{array}$ & \multirow{2}{*}{ 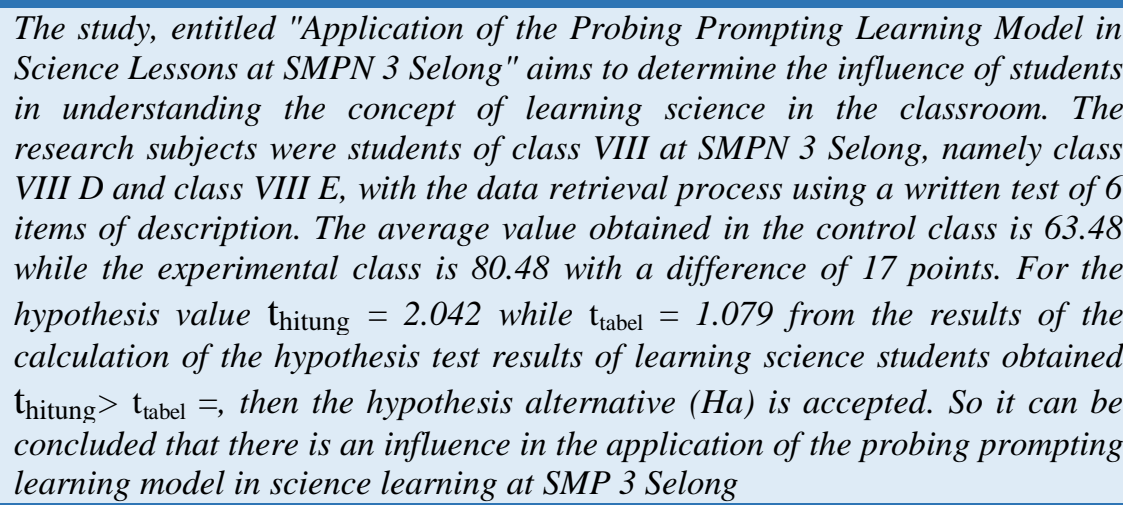 } \\
\hline $\begin{array}{l}\text { Key } \\
\text { Pro } \\
\text { lear } \\
\text { lear } \\
\text { outc }\end{array}$ & \\
\hline Info & Abs \\
\hline $\begin{array}{l}\text { Sejarah Artik } \\
\text { Diterima: } 25 \mathrm{~A} \\
\text { Direvisi: } 20 \mathrm{Ju} \\
\text { Dipublikasi: } 3\end{array}$ & \multirow{2}{*}{$\begin{array}{l}\text { Penelitian yang berjudul "Penerapan Model Pembelajaran Probing Prompting } \\
\text { Pada Pelajaran IPA Di SMPN } 3 \text { Selong" bertujuan untuk mengetahui } \\
\text { sebagaimana pengaruh peserta didik dalam memahami konsep pembelajaran } \\
\text { IPA di dalam kelas. Subyek penelitian adalah peserta didik kelas VIII di SMPN } \\
3 \text { Selong yaitu kelas VIII D dan kelas VIII E, dengan proses pengambilan data } \\
\text { menggunakan tes tertulis sebanyak } 6 \text { butir soal uraian. Nilai rata- rata yang } \\
\text { diperoleh di kelas kontrol } 63.48 \text { sedangkan kelas eksperimen sebesar } 80.48 \\
\text { dengan selisih perbendingan sebesar } 17 \text { poin.untuk nilai hipotesis } t_{\text {hitung }}= \\
2,042 \text { sedangkan } t_{\text {tabel }}=1,079 \text { dari hasil perhitungan uji hipotesis hasil belajar } \\
\text { IPA peserta didik didapatkan nilai } t_{\text {hitung }}>\mathrm{t}_{\text {tabel }} \text {, maka hipotesis alternatif }\left(\mathrm{H}_{\mathrm{a}}\right) \\
\text { diterima. Maka dapat ditarik kesimpulan bahwa ada pengaruh dalam penerapan } \\
\text { model pembelajaran probing prompting dalam pembelajaran IPA di SMP } 3 \\
\text { Selong. }\end{array}$} \\
\hline $\begin{array}{l}\text { Kata kı } \\
\text { Probing } \\
\text { Pembel } \\
\text { belajar. }\end{array}$ & \\
\hline
\end{tabular}

Sitasi: Ismatulloh, K., Ropikoh, R. (2021). Penerapan Model Pembelajaran Probing Prompting pada Pembelajaran IPA Di SMP 3 Selong. Kappa Journal, 5(1) 137-141.

\section{PENDAHULUAN}

Menurut Trianto (2010:1) "pendidikan yang mampu menjawab tujuan nasional adalah pendidikan yang mampu mendukung pembangunan di masa mendatang, pendidikan yang mampu mengembangkan potensi peserta didik sehingga yang bersangkutan mampu menghadapi dan memecahkan masalah kehidupan yang dihadapinya dan pendidikan yang mampu menyentuh potensi nurani maupun kompetensi peserta didik". Jelas bahwa pendidikan yang baik adalah pendidikan yang tidak hanya mempersiapkan siswanya untuk suatu profesi atau jabatan, tetapi hendaknya siswanya dipersiapkan untuk menyelesaikan 
masalah-masalah yang dihadapinya dalam kehidupan sehari-hari. Terkait dengan hal tersebut kegiatan proses belajar-mengajar dikelas seharusnya menerapkan suatu strategi belajar yang kreatif dan inovatif sehingga dapat membantu siswa untuk memahami materi ajar dan aplikasi serta relevansinya dalam kehidupan sehari-hari.

Masalah utama dalam pembelajaran pada pendidikan formal (sekolah) dewasa ini adalah masih rendahnya daya serap peserta didik. Hal ini tampak dari rerata hasil belajar peserta didik yang senantiasa masih sangat memprihatinkan. Prestasi ini tentunya merupakan hasil kondisi pembelajaran yang masih bersifat konvensional dan tidak menyentuh ranah dimensi peserta didik itu sendiri, yaitu bagaimana sebenarnya belajar itu. Dalam arti yang lebih substansial, bahwa proses pembelajaran hingga dewasa ini masih memberikan dominasi guru dan tidak memberikan akses bagi anak didik untuk berkembang secara mandiri melalui penemuan dalam proses berpikirnya.

Ilmu pengetahuan alam merupakan mata pelajaran yang mengkoordinasikan berbagai disiplin ilmu sublintas mata pelajaran seperti biologi, fisika, kimia, geologi, dan antariksa. Selain itu dalam kondisi ketergantungan hidup manusia akan ilmu dan teknologi yang sangat tinggi, maka pembelajaran IPA di SD harus dijadikan sebagai mata pelajaran dasar dan diarahkan untuk menghasilkan warga Negara yang melek IPA (Julia Rikawati;2014). Sebenarnya ilmu pengetahuan alam dapat juga dipadukan dengan mata pelajaran lain di luar bidang kajian ilmu pengetahuan alam, karena ilmu pengetahuan alam bukan sekedar gabungan dari biologi, fisika, kimia, dan antariksa tetapi juga merupakan integrasi kajian ilmu alamiah (Mujakir, 2015). Aspek pokok dalam pembelajaran IPA adalah peserta didik mampu menyadari keterbatasan dalam memahami pembelajaran di kelas dan meningkatkan rasa ingin tahu pada masalah- masalah yang timbul dalam proses pembelajaran di dalam kelas. Kedudukan guru sangatlah penting dalam hal tersebut, guru diminta harus lebih berinovasi dan berfariatif dalam menggunakan model pembelajaran yang akan dignakan dalam proses pembelajaran dalam kelas, salah satunya dengan menggunakan model pembelajaran probing prompting.

Model pembelajaran probing-prompting merupakan pembelajaran yang dapat mengembangkan dan meningkatkan kemampuan berpikir kritis siswa, karena siswa ikut terlibat secara langsung dalam proses pembelajaran. Siswa diberikan serangkaian pertanyaanpertanyaan tingkat tinggi yang sifatnya menuntun dan menggali, sehingga terjadi proses berpikir tingkat tinggi pula yang mengaitkan pengetahuan sikap siswa dan pengalamannya dengan pengetahuan yang baru yang sedang dipelajari. Kemampuan berpikir tingkat tinggi tersebut yaitu kemampuan berpikir kritis.(Elsa Susanti; 2017)

Untuk mencapai tujuan pembelajaran yang diinginkan maka dititik beratkan pada upaya dan usaha guru dalam mendorong dan membiasakan diri untuk lebih berfikir kreatif dan stategi apa saja yang akan digunakan di dalam kelas sehingga peserta didik gampang dalam menyerap pelajaran dan tidak gampang bosan belajar IPA.

\section{METODE}

Penelitian ini dilakukan pada bulan februari minggu ke dua tahun 2021, dengan subyek penelitian peserta didik kelas VIII SMP 3 Selong. Lokasi penelitian di SMPN 3 Selong. Metode penelitian yang digunakan adalah kuantitatif. Desain penelitian dibagi menjadi dua kelas yaitu kelas kontrol dengan metode biasa yang digunakan oleh guru setempat dan kelas eksperimen dengan menggunakan model pembelajaran probing 
prompting. Pengumpulan data menggunakan tes kemampuan kognitif berbentuk uraian. Uji coba instrument dilaksanakan di SMP Lab.Hamzanwadi Selong kelas VIII A dan B dengan menunjukkan hasil bahwa soal yang telah dibuat valid dan realibel. Perhitungan validitas uji coba instrument dari 7 butir soal yang diujikan ternyata 6 butir soal yang valid dan 1 butir soal yang tidak valid.

\section{HASIL DAN PEMBAHASAN}

Berdasarkan hasil analisis data penelitian didapatkan nilai rata- rata antara kelas kontrol dan kelas eksperimen pada tabel berikut:

Tabel 1. Data nilai kelas kontrol dan kelas eksperimen.

\begin{tabular}{ccc}
\hline Jumlah peserta didik & Kelas kontrol & Kelas eksperimen \\
\hline 29 & 63.48 & 80.48 \\
\hline
\end{tabular}

Berdasarkan data tabel diatas bahwa nilai kelas kontrol 63.48 dan kelas ekseperimen 80.48 maka dapat diartikan bahwa kelas eksperimen dengan menggunakan model pembelajaran probing prompting lebih tinggi dibandingkan kelas kontrol. Model pembelajaran probing prompting lebih efektif digunakan dalam pembelajaran IPA. Menurut (Dian Utami, 2016) Model pembelajaran probing prompting adalah model pembelajaran dengan menyajikan serangkaian pertanyaan yang sifatnya menuntun dan menggali gagasan siswa, sehingga dapat melejitkan proses berpikir yang mampu mengaitkan pengetahuan dan pengalaman siswa dengan pengetahuan baru yang sedang dipelajari. Probing prompting merupakan kegiatan pembelajaran non-konvensional yang efektif, jika digunakan dalam kegiatan mengabstraksi teks negosiasi. Probing prompting berisi sejumlah pertanyaan yang telah disusun oleh guru, dan akan membimbing siswa untuk merangkai abstrak. Probing Prompting sangat cocok sekali digunakan dalam proses pembelajaran khususnya IPA dikarenakan peserta didik mampu mengaitkan pengetahuan dan pengalaman sehingga dapat mengabstraksi permasalahan yang ada dalam pembelajaran di kelas. Itu yang menyebabkan hasil belajar peserta didik menjadi lebih baik dibandingkan proses pembelajaran secara konvensional dengan menggunakan metode ceramah.

Dari hasil analisis atau perhitungan yang dilakukan, maka di dapatkan nilai dari chi kuadrat masing-masing kelas, kelompok dan sel. Hasil analisis tersebut dapat di lihat dalam tabel rangkuman dibawah ini.

Tabel 2. Keputusan Uni Chi Kuadrat

\begin{tabular}{ccccc}
\hline Kelas & $\begin{array}{c}\text { Jumlah } \\
\text { Responden }\end{array}$ & $\mathbf{X}_{\text {hitung }}$ & $\mathbf{X}_{\text {tabel }}$ & Keputusan \\
\hline Kontrol & 29 & $-19,73$ & 11,070 & Terdistribusi Normal \\
\hline Eksperimen & 29 & $-29,87$ & 11,070 & Terdistribusi Normal \\
\hline
\end{tabular}

Berdasarkan kriteria yang ada yaitu apabila $F_{\text {hitung }}<F_{\text {tabel }}$ maka kedua kelompok tersebut berasal dari sampel homogen, artinya kedua kelompok mempunyai kemampuan awal yang sama. Berikut disajikan rangkuman perhitungan dengan menggunakan Uji Varians:

Tabel 3 Rangkuman Uji Homogenitas Data Hasil Belajar Fisika Siswa

\begin{tabular}{|c|c|c|c|c|c|c|}
\hline $\mathrm{NO}$ & Kelas & $\bar{X}$ & SD & $F_{\text {hitung }}$ & $F_{\text {tabel }}$ & Keputusan \\
\hline 1 & Kontrol & 51,5 & 12,91 & \multirow{2}{*}{1,27} & \multirow{2}{*}{2,278} & Homogen \\
\hline 2 & Eksperimen & 56,5 & 14,56 & & & Homogen \\
\hline
\end{tabular}


Setelah terpenuhi persyaratan analisis tersebut, maka dapat dilakukan uji hipotesis untuk memenuhi apakah hipotesis yang telah di ajukan diterima atau ditolak. Dari perhitungan data diperoleh seperti pada tabel di bawah ini:

Tabel 4 Hasil Uji Hipotesis Data Hasil Belajar Fisika Siswa

\begin{tabular}{cccccc}
\hline No & Kelas & N (Sampel) & $\begin{array}{c}\text { Standar } \\
\text { Deviasi (SD) }\end{array}$ & $t_{\text {hitung }}$ & $t_{\text {tabel }}$ \\
\hline 1 & Kontrol & 29 & 12,91 & 2,042 & 1,079 \\
\cline { 1 - 3 } & Eksperimen & 29 & 14,56 & &
\end{tabular}

Dari tabel diatas dapat diketahui nilai $t_{\text {hitung }}=2,042$ sedangkan $t_{\text {tabel }}=1,079$ dari hasil perhitungan uji hipotesis hasil belajar IPA peserta didik didapatkan nilai $t_{\text {hitung }}>t_{\text {tabel }}$, maka hipotesis alternatif $\left(\mathrm{H}_{\mathrm{a}}\right)$ diterima. Maka dapat ditarik kesimpulan bahwa ada pengaruh dalam penerapan model pembelajaran probing prompting dalam pembelajaran IPA di SMP 3 Selong.

Menurut (Megasari dkk, 2018) Pembelajaran probing prompting menuntut siswa untuk lebih aktif dalam memperoleh suatu konsep karena siswa akan berusaha untuk mengembangkan nalarnya dalam menjawab pertanyaan yang diajukan dalam pembelajaran. Pembelajaran probing prompting memposisikan guru untuk dapat menyajikan serangkaian pertanyaan yang sifatnya menuntun dan menggali sehingga terjadi proses berfikir siswa terhadap pengetahuan baru yang sedang dipelajari (Diasputri, 2013). Penggunaan probing prompting sangat membantu dalam proses pembelajaran IPA, dimana pembelajaran IPA seringkali dikatakan pembelajaran yang membosankan dan susah dalam pengerjaannya, maka dari itu probing prompting ini sangat tepat digunakan dalam memecahkan permasalah dalam pembelajaran IPA khususnya pada peserta didik dikalangan SMP.

\section{KESIMPULAN}

Dari hasil analisis data maka dapat ditarik kesimpulan antara kelas konrol yang menggunakan model pembelajaran konvensional dan kelas eksperimen yang menggunakan model pembel;ajaran probing prompting mengalami perbedaan nilai rata- rata. Nilai rata- rata kelas kontrol sebesar 63.48 sedangkan nilai rata- rata kelas eksperimen sebesar 80.48 dengan selisih skor sebesar 17. Perhitungan hipotesisnya $t_{\text {hitung }}=2,042$ sedangkan $t_{\text {tabel }}=1,079$ dari hasil perhitungan uji hipotesis hasil belajar IPA peserta didik didapatkan nilai $t_{\text {hitung }}>t_{\text {tabel, }}, H_{0}$ ditolak. Hal ini dapat disimpulkan bahwa ada pengaruh dalam penerapan model pembelajaran probing prompting dalam pembelajaran IPA di SMP 3 Selong.

\section{SARAN}

Diharapkan untuk penelitian- penelitian selanjutnya apabila menggunakan model pembelajaran yang sama akan mendapatkan nilai yang lebih baik lagi dan para guru di Indonesia lebih berani mengembangkan inovasi dan kreasinya dalam menggunakan model pembelajaran yang tepat dalam pembelajaran IPA.

\section{UCAPAN TERIMA KASIH}

Ucapan terima kasih diucapkan untuk kepala sekolah SMPN 3 Selong yang yang telah memberikan tempat untuk meneliti di sekolah dan para guru bidang studi khususnya IPA yang telah membantu berjalannya proses penelitian sehingga bisa selesai tepat waktu. 


\section{DAFTAR PUSTAKA}

Diasputri A, Sri.N, Warlan S. (2013). Pengaruh Model Pembelajaran Probing Promting Berbantuan Lembar kerja Berstruktur Terhadap Hasil Belajar. Jurnal Inovasi Pendidikan Kimia; Vol 7 No1: 1103-1111. 2013.

Megasari., Sundaryono, Agus, dkk. (2018). Pembelajaran Probing Prompting untuk Meningkatkan Berfikir Kritis Siswa Anggota Kelompok Ilmiah Remaja. Jurnal Pendipa Vol 2 (2), No 163-169. 2018.

Mujakir. (2015). Kreativitas Guru Dalam Pembelajaran IPA di Sekolah Dasar. Lantanida Journal Vol 3, No.1. 2015.

Rikawati, Julia., Kresnadi, Hery., Margiati, K, Y. (2014) Peningkatan Hasi Belajar Siswa Pada Pembelajaran IPA Menggunakan Metode Eksperimen Kelas V Sekolah Dasar. S.Pd Skripsi. Universitas Tanjungpura Pontianak.

Susanti, Elsa. (2017). Penerapan Model Pembelajaran Probing Prompting Untuk Meningkatkan Kemampuan Berfikir Kritis Matenatis Siswa Kelas XI IPA MAN 1 Kota Bengkulu. Jurnal Pendidikan Matematika Raflesia Vol 2 No 1 tahun 2017.

Trianto. 2010. Pendidikan Nasionali. Jakarta: Erlangga.

Utami, Dian. (2016). Penerapan Model Pembelajaran Probing Prompting dalam Pemblajaran Mengabstraksi Teks Negosiasi Pada Siswa Kelas X SMA/MA.Jurnal Riksa Bahasa Vol 2, No.2. 2016. 